\title{
Relationship Between LBW and the Incidence of Stunting in Toddlers Aged 1-3 Years at the Minasa Upa Health Center, Rappocini district
}

\author{
Athiyah Ulya Arif*, Purnamaniswaty Yunus, Syatirah Jalaluddin
}

Faculty of Medicine, Universitas Islam Negeri Alauddin, Makassar, Indonesia.

\section{ARTICLE INFO}

Article history:

Received:

January 26, 2022

Received in revised form:

February 12, 2022

Accepted:

February 21, 2022

Keywords:

Stunting, toodler, Low Bady weight

\begin{abstract}
ABSTRAK
Background: Stunting is a long-term effect of chronic malnutrition that causes disturbances in a person's physical growth which is characterized by a decrease in growth speed. Unbalanced food intake, LBW (Low Birth Weight Babies), and a history of the disease are the three main factors that play a role in the incidence of stunting. The purpose of this study was to determine the relationship between a history of LBW and the incidence of stunting for toddlers aged 1-3 years at the Minasa Upa Health Center in 2019. Methods: This research is a quantitative study with an observational approach, using a cross-sectional method. Samples were taken by the purposive sampling method. The number of samples is 134 children with the mother of the child as the respondent. The data were processed and analyzed using the Chi-square $\mathrm{p}<0.05$ test in the SPSS program.

Results: The results showed that there was a significant relationship between a history of low birth weight and stunting $(\mathrm{p}=0.000)$ with an OR value of 18.8 which means that children aged 1-3 years who have a history of low birth weight have a risk of 18.8 times experiencing stunting. Interventions that focus on maternal and child health care are needed to reduce the risk of babies with low birth weight and stunting, as well as raise awareness of mothers about the importance of good nutrition for mothers and their children.

Conclusion: Based on this study, it can be concluded that there is a relationship between a history of LBW and the incidence of stunting in toddlers 1-3 years at the Minasa Upa Public Health Centre.
\end{abstract}

Medical and Health Science Journal 


\section{Introduction}

Nutrition has a close relationship with the health and intelligence conditions of each individual because it is a very important element in a person's growth and development. ${ }^{1}$ Malnutrition in childhood is often associated with deficiencies of certain micronutrients and macronutrients. If this situation continues, it will have an impact starting from an increased risk of infectious disease and death, stunted growth and cognitive, motor, verbal, and so on development. ${ }^{2}$

Stunting is a long-term effect of chronic malnutrition that causes disturbances in a person's physical growth which is characterized by a decrease in growth speed. ${ }^{3}$ Stunting is a linear growth disorder that, if it occurs in the golden period of brain development (0-3 years) of a child, will have an impact on poor brain development. The long-term impact of stunting is the disruption of physical, mental, intellectual, and cognitive development.

According to the Unicef Framework, unbalanced food intake, LBW (Low Birth Weight Babies), and a history of the disease are the main factors that play a role in the incidence of stunting, namely: Inappropriate exclusive breastfeeding caused by limited food consumed can lead to unbalanced food intake. ${ }^{4}$

According to Joint Malnutrition Estimates (2018) in 2017 , around $22.2 \%$ or 150.8 million children under five in the world experienced stunting. According to WHO (2018), Indonesia is ranked third with the highest prevalence of stunting in the Southeast Asia/South-East Asia Regional (SEAR) region. The average prevalence of stunting under five in Indonesia from 2005 to
2017 was $36.4 \% .^{5}$ Research in 2018 in Indonesia found that $29.9 \%$ of children under the age of 24 months experienced signs of stunting. Meanwhile, in Makassar the Makassar City Health Office has conducted a survey where the prevalence of stunting for the last three years was $8.75 \%$ in 2017 and 2018 , then $8.61 \%$ in $2019 .^{6}$

In Islam, we have been commanded by Allah SWT. how important it is to provide nutrition and nutrition to children to prevent health problems such as low birth weight and stunting. As His words in the Qur'an Surah Thaha verse 81 which means "Eat of the good provisions that we have given you and do not exceed the limits". In addition to the above verse, in the Qur'an Surah Al-Baqarah verse 233 is also explained about the recommendation of breastfeeding for 2 years to prevent stunting in children. The verse has the meaning "mothers should breastfeed their children for two full years, that is for those who want to improve breastfeeding..." ${ }^{7}$

\section{Methods}

The total sample in this study amounted to 134 samples. The research design used in this study was observational with a cross-sectional approach. The data used are primary data and secondary data. Primary data was obtained from questionnaires, while secondary data was obtained from research institutions in the form of medical records. Data collection aims to determine the relationship between the history of LBW and the incidence of stunting in children aged 1-3 years at the study site. Analysis of the data used in this study using the SPSS application, which first tested the univariate analysis and then continued with the bivariate analysis using the Pearson Chi- 
Square. Then the hypothesis test was carried out using simple regression analysis.

\section{Results}

Based on the results of research and data processing carried out, the results of the research are presented as follows:

Table 1. Frequency distribution of respondent characteristics and samples of children aged 1-3 years at the Minasa Upa Health Centre in 2019.

\begin{tabular}{|c|c|c|c|c|}
\hline \multirow[t]{3}{*}{ Charachteristic } & \multicolumn{4}{|c|}{ Stunting } \\
\hline & \multicolumn{2}{|c|}{ Stunting } & \multicolumn{2}{|c|}{ Not Stunting } \\
\hline & $\mathbf{n}$ & $\%$ & $\mathbf{n}$ & $\%$ \\
\hline \multicolumn{5}{|l|}{ Gender } \\
\hline Male & 29 & 41,4 & 41 & 64,1 \\
\hline Female & 41 & 58,6 & 23 & 35,9 \\
\hline \multicolumn{5}{|l|}{ Age } \\
\hline 1 year age & 27 & 38,6 & 23 & 35,9 \\
\hline 2 year age & 23 & 32,9 & 18 & 28,1 \\
\hline 3 year age & 20 & 28,6 & 23 & 35,9 \\
\hline \multicolumn{5}{|l|}{ Mother's education } \\
\hline$<$ High & 32 & 45,7 & 12 & 18,8 \\
\hline \multicolumn{5}{|l|}{ school/equivalent } \\
\hline$\geq$ High & 38 & 54,3 & 52 & 81,3 \\
\hline \multicolumn{5}{|l|}{ school/equivalent } \\
\hline \multicolumn{5}{|l|}{ Eexclusive } \\
\hline \multicolumn{5}{|l|}{ breastfeeding } \\
\hline Yes & 52 & 74,3 & 57 & 89,1 \\
\hline No & 18 & 25,7 & 7 & 10,9 \\
\hline \multicolumn{5}{|l|}{ Economic Status } \\
\hline$<\operatorname{Rp} 2.118 .678$ & 44 & 62,9 & 36 & 36,3 \\
\hline$>$ Rp2.118.678 & 26 & 37,1 & 28 & 43,8 \\
\hline \multicolumn{5}{|l|}{ History of Infection } \\
\hline \multicolumn{5}{|l|}{ Disease } \\
\hline Yes & 36 & 51,4 & 27 & 42,2 \\
\hline No & 34 & 48,6 & 37 & 57,8 \\
\hline \multicolumn{5}{|l|}{ Nutritional Status } \\
\hline$<23,5 \mathrm{~cm}$ & 42 & 60 & 12 & 18,8 \\
\hline$>23,5 \mathrm{~cm}$ & 28 & 40 & 52 & 81,3 \\
\hline
\end{tabular}


The results obtained show that the percentage of stunting is higher in the female sample group (58.6\%). Based on age, the percentage of stunting that is more at risk is in the 1 year age group (38.6\%). Exclusive breastfeeding has no risk of stunting $(89.1 \%)$. Samples who have a history of infectious diseases are at risk for stunting (51.4\%). Respondents with the latest education in the form of high school/equivalent have children who are at risk of stunting (54.3\%). Respondents with poor nutritional status as measured using upper arm circumference during pregnancy are at risk of having stunting children (60\%). Respondents with economic

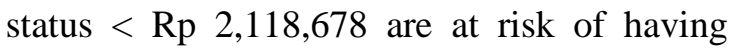
stunting children $(62.9 \%)$.

Table 2. The relationship between the history of LBW and the incidence of stunting in children aged 1-3 years at the Minasa Upa Health Centre in 2019.

\begin{tabular}{|c|c|c|c|c|c|c|c|c|}
\hline \multirow[t]{3}{*}{ Birth Weight } & \multicolumn{4}{|c|}{ Stunting } & \multirow{2}{*}{\multicolumn{2}{|c|}{ Amount }} & \multirow[t]{3}{*}{$P$ value } & \multirow[t]{3}{*}{ OR } \\
\hline & \multicolumn{2}{|c|}{ Stunting } & \multicolumn{2}{|c|}{ Not Stunting } & & & & \\
\hline & $\mathrm{n}$ & $\%$ & $\mathrm{n}$ & $\%$ & $\mathrm{~N}$ & $\%$ & & \\
\hline LBW & 39 & 29,1 & 4 & 3,0 & 43 & 32,1 & $p=0,000$ & 18,8 \\
\hline Not LBW & 31 & 23,1 & 60 & 44,8 & 91 & 67,9 & & \\
\hline Total & 70 & 52,2 & 64 & 47,8 & 134 & 100 & & \\
\hline
\end{tabular}

Based on the table above, it shows that of the 43 samples with a history of low birth weight (LBW), there were 39 people $(90.7 \%)$ who had a history of LBW with stunting, and 4 people $(9.3 \%)$ were not stunted.

The results of the analysis to see the relationship between low birth weight infants (LBW) and the incidence of stunting using the Pearson Chi-Square statistical test, obtained the value of $\mathrm{X} 2 \mathrm{p}=0.000(\mathrm{p}<0.05)$ with an OR value of 18.8. It can be concluded that there is a significant relationship between the history of low birth weight infants (LBW) and the incidence of stunting. Children who have a history of LBW have an 18.8 times risk of becoming stunted compared to children born with normal birth weight or not LBW.

\section{Discussion}

The frequency distribution of children's characteristics shows that the age of most children experiencing stunting is 1 year as many as 27 children (38.6\%). At the age of 1 year, many changes occurred, such as changes in their diet from breast milk to solid food, and some of them began to have difficulty eating. Therefore, if not properly cared for, toddlers will be susceptible to diseases such as infectious diseases. ${ }^{8}$

Based on the results of this study also showed that the majority of children experiencing stunting had a history of infectious diseases, namely 36 children (51.4\%). Malnutrition and infectious diseases have a relationship with each other, which if working together will contribute to the worse. 
Inadequate nutrition can worsen the child's body in dealing with infectious diseases. This shows that there is a relationship between nutritional status and infectious diseases, that is, any infectious disease will worsen nutritional status. ${ }^{9}$ The incidence of recurrent infectious diseases not only affects the child's weight loss but also affects height according to age. ${ }^{10}$

Based on the characteristics of the sample, namely exclusive breastfeeding, according to the results of the study, it was found that the majority of children with exclusive breastfeeding did not experience stunting, namely 57 children (89.1\%). Breast milk is the best food for babies immediately after birth. For the baby's nutrition to be fulfilled, breast milk is needed during the growth period. Stunting can be caused by a lack of nutrition in a child caused by the baby's inability to get breast milk. ${ }^{11}$

This is in line with research conducted by Fitri (2018) which said that of the 55 children under five who were not exclusively breastfed, $23(41.8 \%)$ of them experienced stunting. Meanwhile, toddlers who are exclusively breastfed have a lower risk of stunting, which is only 2 people (10\%). The low level of exclusive breastfeeding is one of the triggers for stunting in children and can have an impact on the child's future, on the contrary, good breastfeeding by the mother will help maintain a child's nutritional balance so that normal child growth is achieved. ${ }^{4}$

Based on the characteristics of the respondents, in this case, mothers of children, the majority of mothers with poor nutritional status are at risk of having stunting children, which are 42 people $(60 \%)$. One way to determine the nutritional status of pregnant women is by measuring the upper arm circumference (LILA). LILA is used to determine if a person suffers from Chronic Energy Deficiency (CED). Pregnant women at risk of CED have a high risk of giving birth to babies with low birth weight. Babies born with LBW will have a risk of malnutrition, growth disorders, impaired child development, and even death. ${ }^{12}$ This is in line with Subekti (2014) which showed that LILA $<23.5 \mathrm{~cm}$ had a 1.95 times greater risk of giving birth to low birth weight. ${ }^{13}$

There are 44 children aged 1-3 years who are stunted and have families with low economic status in the working area of the Minasa Upa Health Center (62.9\%), and 36 people who do not experience stunting (56.3\%). The economic status of the household is one factor in the possibility that a child will be thin and short because it forms the lifestyle of a family. The adequate family economic status will support the development of the child's body. Therefore, WHO recommends stunting or stunting as a measure of low socioeconomic status and as an indicator to monitor equity in health. ${ }^{14-15}$

The characteristics of the mother's recent educational history indicate that the percentage of stunting is higher in the group of mothers with the last education of high school, which is 38 people $(54.3 \%)$. The level of education of parents will affect the process of growth and development of children. A high and good 
education can be ascertained to know about good nutrition too. ${ }^{14,16-17}$

Based on the results of the study of the relationship between the history of LBW and the incidence of stunting, a p-value of 0.000 $(\mathrm{p}<0.05)$ was obtained with an OR value of 18.8. This shows that there is a relationship between a history of LBW and the incidence of stunting in children aged 1-3 years in the working area of the Minasa Upa Health Centre in 2019. Children aged 1-3 years who have a history of low birth weight have an 18.8 times risk of experiencing stunting.

In this study, it was found that from 134 samples, there were 70 children diagnosed with stunting by doctors and 64 children who did not suffer from stunting. Of the 70 children who suffer from stunting, 39 of them have a history of low birth weight (LBW). Birth weight in general is closely related to the process of growth and development in the future because one of the effects is growth faltering. ${ }^{16}$ This result is in line with the research conducted by Yeyen Supriyanto, et al (2017) in Yogyakarta which said that LBW had a significant relationship to the incidence of stunting. ${ }^{10}$

The results of this study are by the recommendations in the Qur'an to pay attention to the welfare of a child by providing adequate nutrition to children. Good nutrition during pregnancy and childbirth can prevent the incidence of LBW which can have an impact on child growth and development. As mentioned in a passage in surah An-Nisa verse 9 which has the meaning "And let those who fear Allah, if they leave behind them weak children, whom they fear for (their welfare). Therefore let them fear Allah and let them speak the truth". ${ }^{7}$

This study has several limitations, such as the delay in the data collection process due to the current condition, namely the Covid 19 pandemic. Many employees at the Minasa Upa Health Centre have to self-isolate so that researchers are hampered in obtaining secondary data.

\section{Conclusion}

Based on the results of this study, it can be concluded that there is a significant relationship between LBW and the incidence of stunting in children aged 1-3 years. Where children aged 13 years who have a history of low birth weight have an 18.8 times risk of experiencing stunting.

\section{Acknowlegment}

The financing is obtained independently

\section{Conflicts of Interest}

There are no conflicts of interest declared by the author.

\section{References}

1. Proverawati A, Kusumawati E. ILMU GIZI. Yogyakarta: Medical Book; 2011.

2. WHO. Global Nutrition Targets 2025 Stunting Policy Brief. Can Pharm J. 2014;122(2):74-6, 78.

3. Habimana S, Biracyaza E. $<\mathrm{p}>$ Risk Factors Of Stunting Among Children Under 5 Years Of Age In The Eastern And Western Provinces Of Rwanda: Analysis 
Of Rwanda Demographic And Health Survey 2014/2015</p>. Pediatr Heal Med Ther. 2019; Volume 10:115-30. Doi: 102147/PHMT.S222193

4. Fitri L. Hubungan BBLR Dan Asi Ekslusif Dengan Kejadian Stunting Di Puskesmas Lima Puluh Pekanbaru. J Endur. 2018;3(1):131-7.

http://doi.org/10.22216/jen.v3i1.1767

5. Kemenkes RI. Buletin Stunting. Kementeri Kesehat RI. 2018;301(5):1163-78.

6. Dinas Kesehatan Kota Makassar. Profil kesehatan Kota Makassar 2015. Dinas Kesehat Kota Makassar. 2016;14-5.

7. Agama K. Syamil Al-Qur'an dan Terjemahannya. Bandung: PT Syamil Cipta Media; 2012.

8. Azriful A, Bujawati E, Habibi H, Aeni S, Yusdarif Y. Determinan Kejadian Stunting Pada Balita Usia 24-59 Bulan di Kelurahan Rangas Kecamatan Banggae Kabupaten Majene. Al-sihah Public Heal Sci J. 2018;10(2):192-203.

https://doi.org/10.24252/as.v10i2.6874

9. Adriana M, Wirjatmadi B. Gizi dan Kesehatan Balita. Jakarta: Kencana. 2014;121.

10. Putra O. Pengaruh BBLR Terhadap Kejadian Stunting Pada Anak Usia 12 - 60 Bulan Di Wilayah Kerja Puskesmas Pauh Pada Tahun 2015. Univ Andalas. 2016; http://scholar.unand.ac.id/12188/

11. Losong NHF, Adriani M. Perbedaan Kadar Hemoglobin , Asupan Zat Besi , dan Zinc pada Balita Stunting dan Non Stunting The Differences of Hemoglobin Level, Iron, and Zinc Intake in Stunting and non Stunting Toodler. Amerta Nutr. 2017;117-23. http://dx.doi.org/10.20473/amnt.v1i2.201 7.117-123

12. Kristiyanasari W. Gizi Ibu Hamil. Nuha Medika; 2010.

13. Subekti R. Analisis Faktor Risiko Kejadian Berat Badan Lahir Rendah di Kabupaten Banjarnegara. Univ Diponegoro. 2014; http://eprints.undip.ac.id/45287/

14. Pramitha A. Faktor-faktor yang Berhubungan Dengan Kejadian Stunting Pada Balita 25- 60 Bulan Di Kelurahan Kalibaru Depok Tahun 2012. 2012. http://lib.ui.ac.id/bo/uibo/detail.jsp?id=20 320460\&lokasi=lokal

15. Soetjiningsih. Tumbuh Kembang Anak. Penerbit Buku Kedokteran : EGC; 2014.

16. Oktarina Z, Sudiarti T. Faktor Risiko Stunting Pada Balita (24-59 Bulan) Di Sumatera. Gizi dan Pangan. 2013;8(November):175-80. Doi: https://doi.org/10.25182/jgp.2013.8.3.177 $-180$ 